\title{
The Relevance of Financial Statements in the Industrial Revolution 4.0 Era
}

\author{
Haryani Chandra $^{1 *}$; Chandra Ferdinand Wijaya ${ }^{2}$ \\ ${ }^{1-2}$ Accounting Department, Faculty of Economics, Universitas Katolik Parahyangan \\ Jln. Ciumbuleuit No. 94, Jawa Barat 40141, Indonesia \\ 'haryanichandra@unpar.ac.id; ${ }^{2}$ chandra.ferdinand@unpar.ac.id
}

Received: $17^{\text {th }}$ November 2020/ Revised: $11^{\text {th }}$ January $2021 /$ Accepted: $4^{\text {th }}$ February 2021

How to Cite: Chandra, H., \& Wijaya, C. F. (2021). The Relevance of Financial Statements in the Industrial Revolution 4.0 Era. Binus Business Review, 12(1), 75-84. https://doi.org/10.21512/bbr.v12i1.6802

\begin{abstract}
The emergence of Industrial Revolution 4.0 has a significant impact on the business processes. It is also expected to change the characteristics of the needed accounting information. The close ties between accounting and the Industrial Revolution 4.0 encourages researchers to conduct research regarding the correlation between the two fields. The research aimed to discuss the characteristics of companies in the Industrial Revolution 4.0 era and identify whether a mismatch occurred between the information in the financial statements and the changes in the characteristics of companies in the Industrial Revolution 4.0 era. It was a narrative literature review using secondary data from various sources. Data collection was made through library research. Then, the data were analyzed using content analysis. The results show that more and more digital-based companies emerge and develop with a remarkably high company value even without having any underlying asset. On the other hand, several studies indicate that assets as an element of financial statements are necessary for determining the company value for allocating economic resources effectively. However, some studies explain that companies with high assets have a high company value. It shows a gap that makes the relevance of financial statements in determining the company value in the Industrial Revolution 4.0 era questionable. This matter has implications for stakeholders to use financial statements for decision-making in Industrial Revolution 4.0 era and future research.
\end{abstract}

Keywords: company characteristics, financial statements, Industrial Revolution 4.0

\section{INTRODUCTION}

Various advanced technologies are created, developed, and used by the wider community to facilitate human life. Amid the rapid development of technology today, a new term has emerged, namely Industrial Revolution 4.0. The latter can be felt to have a very significant impact on various fields of science that exist. Prasetyo and Sutopo (2017) revealed that the emergence of the Industrial Revolution 4.0 had a large impact on industrial, economic, and social conditions in the global community.

The concept of the Industrial Revolution 4.0 has not been widely spread, but it has great opportunities to change various aspects of human life (Fauzan, 2018). It is synonymous with technological developments that are equipped with sensors and can communicate on their own with information technology systems
(Prasetyo \& Sutopo, 2017). The Industrial Revolution 4.0 emerges as a result of the merging of digital technology and conventional Internet technology to enable the integration of all operational activities (Davies, 2015). It subsequently pioneered the emergence of the fourth technological revolution with technological characteristics, such as cyber-physical systems, the Internet of Things (IoT), and the Internet of Services (IoS) (Roblek, Meško, \& Krapež, 2016). The characteristics of these technologies enable the interaction and exchange of information between humans, humans and machines, and even between machines that take place continuously through the Internet network. These technological developments have led to the emergence of the Industrial Revolution 4.0. The word 4.0 is a continuation of three previous revolutions (Fauzan, 2018). The first Industrial Revolution relates to mechanization, and the second 
is the extensive use of electricity. The third relates to digitalization (Lasi, Fettke, Kemper, Feld, \& Hoffmann, 2014).

The Industrial Revolution 4.0 can change the company's activities as a whole so that all involved parties in business activities must prepare themselves to remain competitive in its era. It also has the potential to create a change in the business process. Hence, it can create new business models based on technology. The impact caused by the Industrial Revolution 4.0 will certainly provide its challenges for various fields of science and real practice, including accounting.

The results of the accounting system are financial statements. It is used to provide information for decision-making, such as pricing decisions, lending decisions, and other important economic decisions (Sriwiyanti, 2016; Mohamed, Yasseen, \& Nikhi, 2020). Moreover, the accounting information can be used by various parties, including investors, creditors, governmental agencies, and other potential stakeholders in or out of the organization (Mohs, 2017).

Accounting is a business language and a method used by companies to communicate financial information to corresponding parties (Prasad, Mubeen, \& Rajani, 2020). Financial statements are the main means for companies to communicate financial information to parties outside the company. It presents information about the assets, liabilities, equity, income, and expenses of an entity (International Accounting Standards Board, 2018). Accounting as a business language continues to develop. It can differ between countries and sectors (Morais, Fialho, \& Dionísio, 2018). As part of the business process, accounting has undergone various changes (Surianti, 2020). It aims to present accurate information so that investors can avoid wrong investment decisions. The previous industrial revolution has broadened the focus of accounting not only on the recording and reporting process but also on the analysis of information for economic decision-making by the management in charge (Noviari, 2007; Slyozko \& Zahorodnya, 2016).

The emergence of new technology-based business models due to the Industrial Revolution 4.0 leads to the need to adopt accounting that is more directed towards the characteristics of this specific revolution. By understanding it, it is expected that accountants, business people, accounting policymakers, and regulators can provide accounting information to support economic decision-making. Without understanding this revolution, the provided accounting information in financial reports and other reports can be irrelevant and cannot support decision making. Even worse, accounting information that is not adjusted to the latest developments in its business processes can mislead decision-makers. Decisionmakers can make decisions that are detrimental to themselves and the company. However, it can also have an impact on the general public or society at large.

The previous researchers examine the publications, which include the title of Industry 4.0. It shows that more than $50 \%$ of the previous articles are in the manufacturing area without mentioning research in the accounting sector (Prasetyo \& Sutopo, 2018). However, some previous studies have discussed topic about how Industrial Revolution 4.0 changes accounting practices, especially the challenges that accountants face in this era (Arwani, 2020; Rosmida, 2019; Rini, 2019), and education (Adriana, Amalia, \& Utami, 2020; Supriadi, Rahardjo, \& Suprihandari, 2020; Surianti, 2020). The previous studies agree that Industrial Revolution 4.0 has a significant impact on accounting but does not examine financial statements as the main accounting product. The existence of a small amount of research on the relationship between the Industrial Revolution 4.0 and accounting, especially about financial statements, encourages the researchers to research the Industrial Revolution 4.0 and accounting. Hence, it is expected to reach a clear understanding of its influence on accounting in the future.

The research aims to discuss the characteristics of companies in the Industrial Revolution 4.0 era and identify whether a mismatch occurs between the information in the financial statements and the changes in the characteristics of companies in the Industrial Revolution 4.0 era. The research is expected to be useful for stakeholders to obtain an overview regarding the relevance of accounting information presented in financial statements during the Industrial Revolution 4.0. That overview is expected to help them to make more precise decisions about allocating economic resources and giving insight into future research.

\section{METHODS}

The research applies the narrative literature review. It is carried out by conducting studies derived from various kinds of background literature as secondary data from various sources. Data collection is done through library research. Researchers search and gather information from various background literature, such as books, articles, and websites related to the Industrial Revolution 4.0 and accounting. The related topics include companies in the Industrial Revolution 4.0 and financial statements, especially how stakeholders use the provided information in financial statements. The data analysis method is content analysis. Researchers analyze the data obtained from the literature. The data are analyzed to find the gap between them. Hence, it can produce conclusions that address the formulation of the problem

\section{RESULTS AND DISCUSSIONS}

The Industrial Revolution 4.0 is a digital revolution marked by the advancement of science and technology. It provides a breakthrough in several fields, such as artificial intelligence robots, nanotechnology, biotechnology, quantum computer technology, blockchain, and 3D printers (Maryanti, 
Rohana, \& Kristiawan, 2020). Nine technological advances underlie the Industrial Revolution 4.0. There are big data and analytics, autonomous robots, simulation, horizontal and vertical system integration, industrial IoT, cybersecurity, the cloud, additive manufacturing, and augmented reality (Rüßmann et al., 2015). These technological advances change the production process to be integrated, automatic, and optimal in the production flow. This change in the production process leads to greater efficiency and change in relations between suppliers, producers and customers, and people and machines.

As stated previously, Industrial Revolution 4.0 has brought significant changes to technology. The use of technology is an integral part of every company. Therefore, Industrial Revolution 4.0 concept is not only directly applied to the manufacturing process of a company but also completed the value chain (Rojko, 2017). As a result, the companies besides manufacturing companies will also experience changes due to Industrial Revolution 4.0.

Industrial Revolution 4.0 has also changed the business model trends used by companies. In general, there are four business models in a company: developing and selling physical objects (asset builders), employing employees to provide services to customers (service providers), selling intellectual property (technology creators), and creating networks as a place for various participants to interact and share value creation (network orchestrators). The examples of companies with network orchestrator business models are eBay, Uber, Alibaba, and TripAdvisor (Nurlansa \& Jati, 2016). The Industrial Revolution 4.0 encourages the rise of network orchestrators. This statement has been reinforced by Bianchi and Labory (2018). The focus of many industries has now shifted from selling products to delivering services because of the increasing number of customers who no longer buy and own physical objects but pay for services accessed through digital platforms.

Several studies are cited, and based on the analysis results, companies with a network orchestrator business model have three to four times company value more than other business models. Even over the past decade, the gap between the value of network orchestrator companies and other companies has widened. The way companies create their value has changed (Nurlansa \& Jati, 2016). In the Industrial Revolution 4.0, companies can create welfare values with fewer employees than 10 to 15 years ago. In addition, there is also a change in the role of capital and business scale. For example, Instagram and WhatsApp only need a small amount of capital to start their business enterprises (Bianchi \& Labory, 2018).

A measurement to measure the company value is the price-to-revenue ratio. This ratio shows how much investors are willing to pay or assess each sale made by the company (Vruwink, Quirin, \& O'Bryan, 2007). The analysis of the company's price-to-revenue ratio comparison for each business model shows that companies with network orchestrator business models have the highest price-to-revenue ratio compared to companies with other business models. It also has the highest revenue and profit growth (Nurlansa \& Jati, 2016). It shows that the company with a network orchestrator business model has a good company performance in addition to having the highest company value.

In the facing Industrial Revolution 4.0, which is full of changes, companies must adapt to changing operating models and strategies to sustain and create company value. The operating model and strategy that can be applied is the platform strategy (Bianchi \& Labory, 2018). A distinctive feature of the Industrial Revolution 4.0 is the emergence of global platforms that are closely connected to the physical world. The platform strategy combines the need to focus more on customers to improve the products with data. It has changed the company's focus from selling products to delivering services. More and more customers no longer buy and own goods physically but prefer to pay for services that can be accessed through digital platforms such as listening to songs through Spotify.

The company's business model shifts to a network orchestrator and changes the operating models and strategies, which are more customer-oriented, and focuses on delivering the services coupled with technological developments. Those changes are the result of Industrial Revolution 4.0. It has led to the emergence of companies that do not have their assets but can operate successfully through digital platforms. The use of digital platforms has also enabled the use of digital assets to create company value instead of physical assets. For example, Uber's success starts with improving the customer experience by being able to track the location of the car through a mobile phone, seeing the car standard description, and having a payment process that is not prone to fraud to avoid delays to the destination (Bianchi \& Labory, 2018). This example illustrates the disruption that occurs when digital assets and a combination of digital platforms change the relationship with physical assets. It is the change from having an asset physically to only having access to the asset. For example, a company does not own a car, but a partner (driver) owns the car. It makes the car usable. It can also be that the company does not own a house, but the homeowner makes the house available for rent.

As stated before, the combination of digital assets and digital platforms has enabled the company to operate successfully even without owning assets. In connection with accounting, the asset is one of the basic elements in financial statements. Financial statements result from the financial reporting process. The financial reporting aims to present financial information to users in making decisions regarding allocating resources to entities. Decision-making by users of financial statements involves decisions to buy, sell or hold investments in shares or bonds, grant or repay loans, and vote or influence management actions (International Accounting Standards Board, 2018). The purpose of financial reporting is stated in 
the Conceptual Framework for Financial Reporting. Investors and creditors need the company's financial information to allocate their resources to the company effectively. The process of allocating resources from investors and creditors to companies effectively is essential for economic health. It can increase productivity, encourage innovation, present an efficient and liquid market for the buying and selling securities, and obtain and provide loans (Kieso, Weygandt, \& Warfield, 2018).

There are five basic elements of financial statements, namely assets, liabilities, equity, income, and expenses (International Accounting Standards Board, 2018). These elements of the financial statements can be used to calculate financial ratios. Financial ratios can analyze the performance and value of companies (Marsha \& Murtaqi, 2017). Thus, financial statements have an essential role for users in the process of determining the performance and value of the company. It can help users in making decisions regarding the allocation of economic resources.

Various studies have proven the critical role of financial statements, involving information in financial statements as research variables. The studies have been conducted using accounting information presented in financial statements as a proxy that represents the studied research variables. The research variables, which are calculated based on financial statement information, are used to make the decision. The results of these studies encourage investors to use information in the company's financial statements to make decisions regarding the allocation of economic resources owned. Table 1 (see apendix) shows the reference of these studies.

In Table 1 (see apendix), there is an explanation of accounting information in financial statements that are employed as research variables. Various studies have shown that the variables in question must be considered in the decision-making process of economic resource allocation. It can be seen that the presented accounting information in the financial statements has an influence on decision-making concerning the allocation of economic resources. Accounting information can be used by users of financial statements in analyzing the condition and performance of a company. The results of various studies, which as a whole state that investors and creditors should consider accounting information in financial statements when making decisions about the allocation of economic resources. It indicates that financial statements have an important role in the decision-making process. It can be used as a basis for making resource allocation decisions. Moreover, investors and creditors use financial statements to analyze a company to decide which company will be the target of resource allocation.

Furthermore, the results of the various studies up to the latest year, in which the era of Industrial Revolution 4.0 has occurred, still state that accounting information presented in financial statements, including assets, is essential in determining company value for decision-making. On the other hand, the Industrial Revolution 4.0 has changed the company's business processes. Changes in business processes have created many digital-based companies that do not have any underlying assets but high company value. It is previously explained to have an impact on the existence of elements in the financial statements of the company. It causes the reliability and relevance of financial statements to be questioned because financial statements do not provide a real picture of the company. Companies that can actually benefit investors and creditors can look bad due to bad financial ratios so that economic resources are not effectively allocated. The previous research also questions whether it is still important for companies to have underlying assets in the context of economic changes in the Industrial Revolution 4.0 era (Bianchi \& Labory, 2018).

This doubt is reinforced by Bianchi and Labory (2018) by quoting Tom Goodwin's article in the TechCrunch article. As the largest taxi provider company in the world, Uber has no vehicles, and Facebook, as the most popular media owner in the world, does not create any content. Similarly, Alibaba, as the most valuable retailer in the world, has no inventory. Meanwhile, Airbnb, as the biggest accommodation provider, has no real estate. It is a sign that digital disruption has begun (Demirkan, Spohrer, \& Welser, 2016).

Companies that use digital platforms are well known and have a large business scale. Facebook and Alibaba are digital companies that ranked among the 100 best versions of Forbes Magazine in 2018. Uber is a giant technology company that has been reported to be worth more than $\$ 60$ billion, and Airbnb is worth around \$25 billion (Dawson, Hirt, \& Scanlan, 2016). The digital companies in Southeast Asia are also growing so rapidly that they have an investment of more than ten billion dollars, dominated by Singapore and Indonesia. Some other examples of successful digital companies are Sea, Razer, Tokopedia, Gojek, and Traveloka (Rahardjo \& Sugiarto, 2019). Gojek, which is one of the unicorns in Indonesia, has reached a company value of up to 3 billion Dollars (Azzuhri, Syarafina, Yoga, \& Amalia, 2018).

The emergence of the Industrial Revolution 4.0 encourages more and more network type companies to operate using digital platforms. Thus, the Industrial Revolution 4.0 has given rise to many digital companies that do not have underlying assets but can achieve high company value. In other words, assets as elements presented in the financial statements do not determine the level of the company value. However, as described in Table 1 (see apendix), other recent studies still explain that the accounting information in financial statements (assets, debt, equity, income, and expenses) is important for determining the company value in the decision-making process about source allocation of economic power.

The explanation from existing studies shows that there is a gap. The financial statements are still considered important in helping users to assess the 
company to make decisions on the allocation of economic resources. On the other hand, the elements of financial statements cannot be used in determining the company value due to digital disruption arising from Industrial Revolution 4.0. This gap raises questions about the relevance of the role of financial statements as a tool to assess companies in the framework of the decision-making process of economic resource allocation in the Industrial Revolution 4.0 era. As a result, users of financial statements find it increasingly difficult to determine the company value in this era of digital disruption so that the challenges in making effective decisions are even more daunting.

The purpose of financial statements as described in the Conceptual Framework for Financial Reporting is questionable in terms of relevance in determining the company value for the decision-making about allocating economic resources in Industrial Revolution 4.0 era. It is structured to be used as a tool for the International Accounting Standards Board (IASB) to compile International Financial Reporting Standards (IFRS) consistently. Hence, it can produce useful financial information for investors and creditors as a tool for preparing financial statements and for all parties involved in understanding and interpreting accounting standards (International Accounting Standards Board, 2018). The doubt about the relevance of the objectives of financial statements with the development of the times in the Industrial Revolution 4.0 also raises problems about the relevance of the Conceptual Framework for Financial Reporting.

In addition to the purpose of financial statements, the Conceptual Framework for Financial Reporting also explains that assets are current economic resources that can be controlled by entities due to past events (International Accounting Standards Board, 2018). During the Industrial Revolution 4.0, companies that use resources they cannot control emerge, as explained earlier. For example, Gojek uses its partners' resources. These resources can provide economic benefits for the entity. Still, they cannot be controlled by the entity, so it does not meet the definition as an asset in the financial statements. The financial statements do not reflect the state of the entity that receives these economic benefits.

Moreover, the value of assets in the financial statements becomes too small compared to the actual received economic benefits. In other words, the financial statements do not provide a true or accurate picture of the state of the entity. Therefore, the definition of assets disclosed in the Conceptual Framework for Financial Reporting needs to be reviewed not to mislead users of financial statements, especially in the Industrial Revolution 4.0 era, which has caused digital disruption.

\section{CONCLUSIONS}

Financial statements are a product of accounting used by economic actors to help to decide the allocation of economic resources. Decision-making of economic actors is based on an analysis of the elements of financial statements, namely assets, debt, equity, income, and expenses. The era and the existence of the Industrial Revolution 4.0 have brought significant changes related to science and technology. These changes have resulted in changes to the company's business model and how the company operates, leading to digital disruption. It is shown by the emergence of digitalbased companies. These digital-based companies operate without having underlying assets and use the digital platform as a medium of their operations. Even without underlying assets, these companies can achieve a very high company value. However, the asset is one of the five essential elements of financial statements in determining the company value.

Meanwhile, recent previous studies have shown that elements of financial statements are important in valuing a company so that the information can be used for determining the allocation of economic resources more effectively. It calls into questioning the relevance of the role of financial statements in determining the company value in the Industrial Revolution 4.0 era. More in-depth research regarding the financial statement in Industrial Revolution 4.0 is urgently needed to prevent mistaken economic decisionmaking.

The research is limited to the previous literature. Hence, more field research that involves the stakeholders of financial statements is needed. To further explore the role of financial statements in the Industrial Revolution 4.0 era, the next researchers can examine the views of financial statement users more closely, specifically on the relevance of financial statements in decision-making in allocating economic resources. It can be achieved using a questionnaire as a research aid. Moreover, the research is for all stakeholders of financial statements as an insight about financial statements in Industrial Revolution 4.0, so they can use accounting information more wisely. The research also can be used on further research about accounting and Industrial Revolution 4.0.

\section{ACKNOWLEDGEMENTS}

The research was supported by a grant from Universitas Katolik Parahyangan in 2019. The authors wish to express their gratitude for Universitas Katolik Parahyangan.

\section{REFERENCES}

Adenugba, A. A., Ige, A. A., \& Kesinro, O. R. (2016). Financial leverage and firms' value: A study of selected firms in Nigeria. European Journal of Research and Reflection in Management Sciences, 4(1), 14-32.

Adriana, P., Amalia, R., \& Utami, K. (2020). Accounting ethics education in the Industrial Revolution 4.0: An educators perspective. In $1^{\text {st }}$ Annual Management, Business and Economic Conference (AMBEC 2019) (pp. 21-25). Atlantis Press. https://doi.org/10.2991/ 
aebmr.k.200415.005

Akhtar, M. W., Khan, F. A., Shahid, A., \& Ahmad, J. (2016). Effects of debt on value of a firm. Journal of Accounting \& Marketing, 5(4), 1-4. https://doi. org/10.4172/2168-9601.1000202

Arwani, A. (2020). Challenges and prospect to Islamic accountants take on Industrial Revolution 4.0. Jurnal Akuntansi Indonesia, 9(2), 88-105. https:// doi.org/10.30659/jai.9.2.85-105

Azzuhri, A. A., Syarafina, A., Yoga, F. T., \& Amalia, R. (2018). A creative, innovative, and solutive transportation for Indonesia with its setbacks and how to tackle them: A case study of the phenomenal GOJEK. Review of Integrative Business and Economics Research, 7(1), 59-67.

Bianchi, P., \& Labory, S. (2018). The fourth industrial revolution. In Industrial policy for the manufacturing revolution. Edward Elgar Publishing.

Chandra, H. (2019). Pengaruh ukuran perusahaan, rasio aktivitas, dan profitabilitas terhadap pembayaran dividen pada perusahaan rokok yang terdaftar di Bursa Efek Indonesia. Jurnal Riset Akuntansi, 11(2), 1-9. https://doi.org/10.34010/jra.v11i2.2275

Chandra, H., \& Djajadikerta, H. (2017). The influence of intellectual capital, profitability, and leverage on company value in property, real estate, and building construction companies listed on the Indonesia Stock Exchange. Ultima Accounting: Jurnal Ilmu Akuntansi, 9(2), 1-14. https://doi.org/10.31937/ akuntansi.v9i2.726

Cordeiro da Cunha Araújo, R., \& André Veras Machado, M. (2018). Book-to-market ratio, return on equity and Brazilian stock returns. RAUSP Management Journal, 53(3), 324-344. https://doi.org/10.1108/ RAUSP-04-2018-001.

Dang, H. N., Vu, V. T. T., Ngo, X. T., \& Hoang, H. T. V. (2019). Study the impact of growth, firm size, capital structure, and profitability on enterprise value: Evidence of enterprises in Vietnam. Journal of Corporate Accounting \& Finance, 30(1), 144-160. https://doi.org/10.1002/jcaf.22371

Davies, R. (2015). Industry 4.0: Digitalisation for productivity and growth. Retrieved from https:// www.europarl.europa.eu/thinktank/en/document. html?reference=EPRS_BRI\%282015\%29568337

Dawson, A., Hirt, M., \& Scanlan, J. (2016). The economic essentials of digital strategy. McKinsey Quarterly, 1-13.

Demirkan, H., Spohrer, J. C., \& Welser, J. J. (2016). Digital innovation and strategic transformation. IT Professional, 18(6), 14-18. https://doi.org/10.1109/ MITP.2016.115

Doğan, M. (2013). Does firm size affect the firm profitability? Evidence from Turkey. Research Journal of Finance and Accounting, 4(4), 53-59.

Fauzan, R. (2018). Karakteristik model dan analisa peluangtantangan Industri 4.0. Phasti: Jurnal Teknik Informatika Politeknik Hasnur, 4(01), 1-11.

Ilaboya, O. J., \& Ohiokha, I. F. (2016). Firm age, size and profitability dynamics: A test of learning by doing and structural inertia hypotheses. Business and
Management Research, 5(1), 29-39. https://doi. org/10.5430/bmr.v5n1p29

International Accounting Standards Board. (2018). Conceptual Framework for Financial Reporting. Retrieved from https://www.ifrs.org/-/media/project/ conceptual-framework/fact-sheet-project-summaryand-feedback-statement/conceptual-frameworkproject-summary.pdf

Isik, O., Unal, E. A. Unal, Y. (2017). The effect of firm size on profitability: Evidence from Turkish manufacturing sector. Journal of Business, Economics and Finance, 6(4), 301-308. https://doi.org/10.17261/ Pressacademia.2017.762

John, A. O., \& Adebayo, O. (2013). Effect of firm size on profitability: Evidence from Nigerian manufacturing sector. Prime Journal of Business Administration and Management (BAM), 3(9), 1171-1175.

Karakus, R., \& Bozkurt, İ. (2017). The effect of financial ratios and macroeconomic factors on firm value: An empirical analysis in Borsa Istanbul. In RSEP International Conferences on Social Issues and Economic Studies (pp. 27-34). https://doi. org/10.19275/RSEPCONFERENCES091

Kieso, D. E., Weygandt, J. J., \& Warfield, T. D. (2018). Intermediate accounting: IFRS edition. Hoboken, NJ : John Wiley \& Sons, Inc.

Lasi, H., Fettke, P., Kemper, H. G., Feld, T., \& Hoffmann, M. (2014). Industry 4.0. Business \& Information Systems Engineering, 6(4), 239-242.

Marsha, N., \& Murtaqi, I. (2017). The effect of financial ratios on firm value in the food and beverage sector of the IDX. Journal of Business and Management, 6(2), 214-226.

Maryanti, N., Rohana, R., \& Kristiawan, M. (2020). The principal's strategy in preparing students ready to face the Industrial Revolution 4.0. International Journal of Educational Review, 2(1), 54-69.

Mohamed, W., Yasseen, \& Nikhi, N. (2020). International Financial Reporting Standards for small and medium-sized entities: A survey showing insights of South African accounting practitioners. Journal of Economic and Financial Sciences, 13(1), 1-9. https://doi.org/10.4102/jef.v13i1.489

Mohs, J. N. (2017). Financial reporting and the accounting expectations gaap. Review of Contemporary Business Research, 6(1), 25-34. https://doi.org/10.15640/rcbr. v6n1a3

Morais, A. I., Fialho, A., \& Dionísio, A., (2018). Is the accounting quality after the mandatory adoption of IFRS a random walk? Evidence from Europe. Journal of Applied Accounting Research, 19(3), 334350. https://doi.org/10.1108/JAAR-07-2016-0073

Mule, K. R., Mukras, M. S., \& Nzioka, O. M. (2015). Corporate size, profitability and market value: An econometric panel analysis of listed firms in Kenya. European Scientific Journal, 11(13), 376-396.

Noviari, N. (2007). Pengaruh kemajuan teknologi informasi terhadap perkembangan akuntansi. Jurnal Ilmiah Akuntansi dan Bisnis, 2(1), 1-14.

Nurlansa, O., \& Jati, H. (2016). Analysis porter's five forces model on Airbnb. Elinvo (Electronics, Informatics, 
and Vocational Education), 1(2), 84-96.

Prasad, K. D., Mubeen, S. A., \& Rajani, B. (2020). Accounting disclosure practices - An over view. Journal of Finance and Accounting, 8(4), 208-211. https://doi.org/10.11648/j.jfa.20200804.16

Prasetyo, H., \& Sutopo, W. (2018). Industri 4.0: Telaah klasifikasi aspek dan arah perkembangan riset.J@ti Undip: Jurnal Teknik Industri, 13(1), 17-26. https:// doi.org/10.14710/jati.13.1.17-26

Prasetyo, H., \& Sutopo, W. (2017). Perkembangan keilmuan teknik industri menuju era Industri 4.0. In Seminar dan Konferensi Nasional IDEC (pp. 488-96).

Rahardjo, D., \& Sugiarto. (2019). Valuation model using a mixed real options method: A review on Singapore and Indonesia digital startups. In $16^{\text {th }}$ International Symposium on Management (INSYMA 2019) (pp. 9-12). Atlantis Press. https://doi.org/10.2991/ insyma-19.2019.3

Rini, Y. T. (2019). Mengurai peta jalan akuntansi era Industri 4.0. Referensi : Jurnal Ilmu Manajemen dan Akuntansi, 7(1), 58-68 . https://doi.org/10.33366/ref. v7i1.1339

Roblek, V., Meško, M., \& Krapež, A. (2016). A complex view of Industry 4.0. SAGE Open, April-June, 1-11. https://doi.org/10.1177/2158244016653987

Rojko, A. (2017). Industry 4.0 concept: Background and overview. International Journal of Interactive Mobile Technologies, 11(5), 77-90.

Rosmida. (2019). Transformasi peran akuntan dalam era revolusi Industri 4.0 dan tantangan era Society 5.0. Inovbiz: Jurnal Inovasi Bisnis, 7(2), 206-212. https://doi.org/10.35314/inovbiz.v7i2.1197

Rüßmann, M., Lorenz, M., Gerbert, P., Waldner, M., Justus, J., Engel, P., \& Harnisch, M. (2015). Industry 4.0: The future of productivity and growth in manufacturing industries. The Boston Consulting Group.

Sadi'ah, K. (2018). The effect of corporate financial ratio upon the company value. The Accounting Journal of Binaniaga, 3(2), 75-88. https://doi.org/10.33062/ ajb.v3i2.245
Siahaan, F. O. P. (2013). The effect of good corporate governance mechanism, leverage, and firm size on firm value. GSTF Journal on Business Review (GBR), 2(4), 137-142.

Slyozko, T., \& Zahorodnya, N. (2016). The fourth industrial revolution: The present and future of accounting and the accounting profession. Polgari Szemle, 1-8.

Sriwiyanti, E. (2016). The application of accounting system at SMES in Pematangsiantar. European-American Journals, 4(9), 60-65.

Sucuahi, W., \& Cambarihan, J. M. (2016). Influence of profitability to the firm value of diversified companies in the Philippines. Accounting and Finance Research, 5(2), 149-153. https://doi. org/10.5430/afr.v5n2p149

Supriadi, I., Rahardjo, K. A., \& Suprihandari, M. D. (2020). Expectations and standards for accounting professions and implications in the learning pattern in Industrial 4.0. Ilomata International Journal of Tax and Accounting, 1(2), 66-73.

Surianti, M. (2020). Development of accounting curriculum model based on industrial revolution approach. Research Journal of Finance and Accounting, 11(2), 116-123. https://doi.org/10.7176/rjfa/11-2-12

Takamatsu, R. T., \& Lopes Fávero, L. P. (2019). Financial indicators, informational environment of emerging markets and stock returns. RAUSP Management Journal, 54(3), 253-268. https:// doi.org/10.1108/ RAUSP-10-2018-0102.

Vruwink, D. R., Quirin, J. J., \& O’Bryan, D. (2007). A modified price-sales ratio: A useful tool for investors? Journal of Business \& Economics Research (JBER), 5(12), 31-40. https://doi.org/10.19030/jber. v5i12.2613

Wijaya, C. F., \& Djajadikerta, H. (2017). Pengaruh risiko sistematis, leverage, dan likuiditas terhadap return saham LQ 45 yang terdaftar pada bursa efek. Ultima Management: Jurnal Ilmu Manajemen, 9(2), 62-76. https://doi.org/10.31937/manajemen.v9i2.721 


\section{APPENDIX}

Table 1 Reference to Various Previous Researchers Using Financial Statement Information as Variables

\begin{tabular}{|c|c|c|}
\hline Research & Variable & Proxy \\
\hline Doğan (2013) & Firm Size & $\begin{array}{l}\text { Logarithm } \\
\text { Total Assets } \\
\text { Natural Logarithm Total Sales }\end{array}$ \\
\hline John and Adebayo (2013) & Firm Size & Log Total Assets \\
\hline Siahaan (2013) & Firm Size & Total Assets \\
\hline Mule, Mukras, and Nzioka (2015) & Firm Size & Logarithm Total Assets \\
\hline Adenugba, Ige, and Kesinro (2016) & Financial Leverage & $\frac{\text { Total Debt }}{\text { Total Equity }}$ \\
\hline $\begin{array}{l}\text { Akhtar, Khan, Shahid, and Ahmad } \\
\text { (2016) }\end{array}$ & Financial Leverage & $\frac{\text { Total Debt }}{\text { Total Equity }}$ \\
\hline Ilaboya and Ohiokha (2016) & Firm Size & Log Total Assets \\
\hline Sucuahi and Cambarihan (2016) & $\begin{array}{l}\text { Profitability } \\
\text { (Return on Assets) }\end{array}$ & $\frac{\text { Net Profit }}{\text { Total Assets }}$ \\
\hline \multirow[t]{2}{*}{ Isik, Unal, and Unal (2017) } & Firm Size & $\begin{array}{l}\text { Natural Logarithm Total Assets } \\
\text { Natural Logarithm Total Sales }\end{array}$ \\
\hline & Return on Assets & $\frac{\text { Net Profit }}{\text { Total Assets }}$ \\
\hline \multirow[b]{3}{*}{ Wijaya and Djajadikerta (2017) } & Net Working Capital Turnover & $\frac{\text { Net Sales }}{\text { Average WC }}$ \\
\hline & Debt to Total Assets & $\frac{\text { Total Debts }}{\text { Total Assets }}$ \\
\hline & Liquidity & $\begin{array}{l}\frac{\text { Current Debts }}{\text { Equity Total }} \\
\text { Current Assets } \\
\text { Current Debts }\end{array}$ \\
\hline
\end{tabular}


Table 1 Reference to Various Previous Researchers Using Financial Statement Information as Variables (Continued)

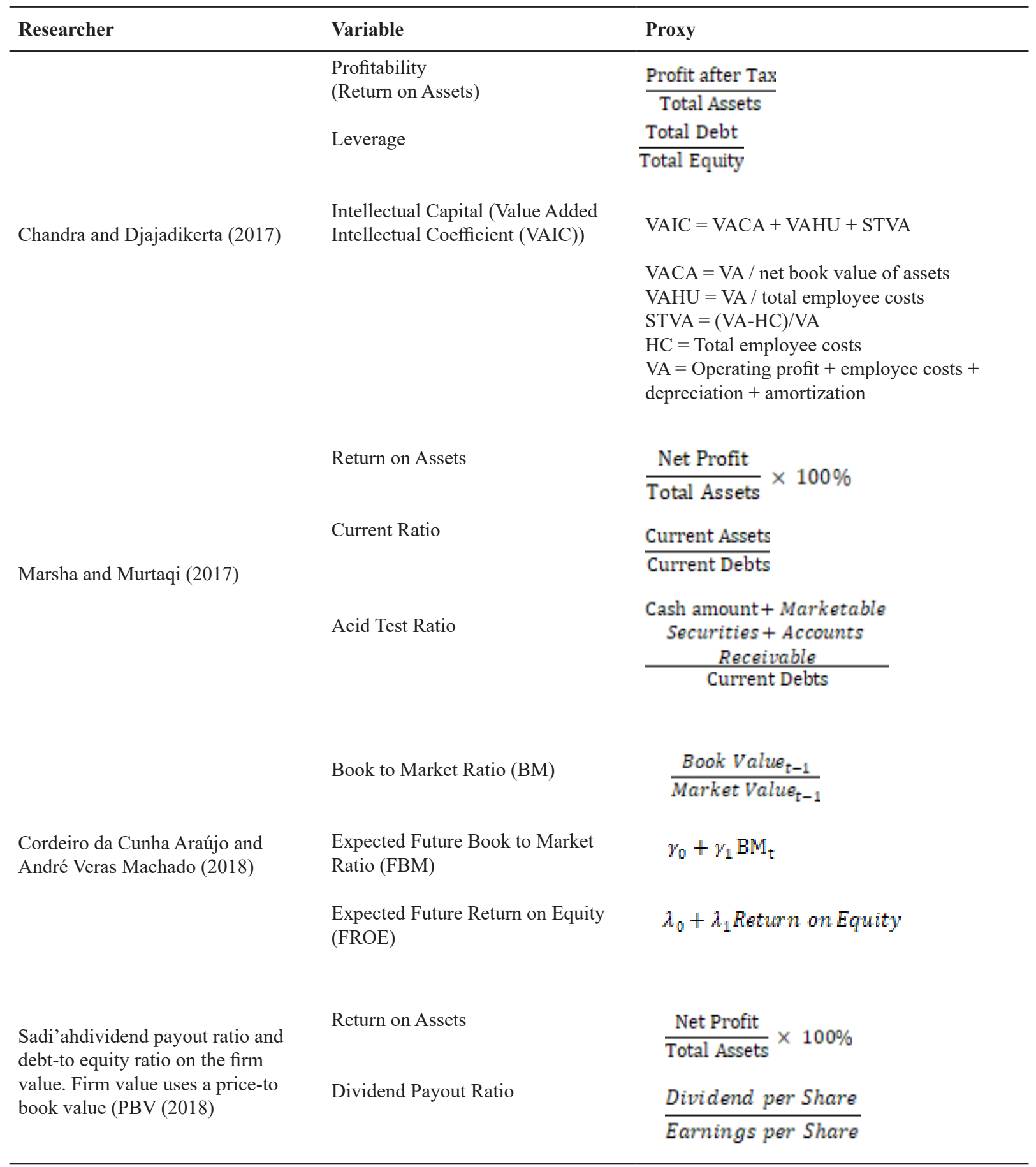


Table 1 Reference to Various Previous Researchers Using Financial Statement Information as Variables (Continued)

\begin{tabular}{lll}
\hline Researcher & Variable & Proxy \\
\hline Dang, Vu, Ngo, and Hoang (2019) & Firm Size & Total Assets \\
& Company Size & Ln (Total Assets) \\
& Price to Book Ratio & $\frac{\text { Market Value }}{\text { Net Equity Value }}$ \\
Takamatsu and Lopes Fávero (2019) & Gross Profitability & $\frac{\text { Gross Profit }}{\frac{1}{2} \times\left(\mathrm{TA}_{\mathrm{t}-1}+\mathrm{TA}_{\mathrm{t}}\right)}$ \\
& Firm Size & Total Assets \\
& Activity Ratio & $\frac{\text { Net Sales }}{\text { Total } \text { Assets }}$ \\
Chandra (2019) & Return on Equity & $\frac{\text { Net Income }}{\text { Total Equity }} \times 100 \%$ \\
& & Total Dividend \\
\hline
\end{tabular}

